\title{
Empirical Research of the Impact of Capital Structure on Agency Cost of Chinese Listed Companies
}

\author{
Mengmeng Zheng ${ }^{1}$ \\ ${ }^{1}$ School of Finance, Shandong University of Finance, Jinan, China \\ Correspondence: Mengmeng Zheng, 40 Shungeng Road, School of Finance, Shandong University of Finance, \\ Jinan, 250014, China. Tel: 86-531-8291-1084. E-mail: zhengmm54@hotmail.com
}

Received: August 12, 2013

Accepted: August 26, 2013 Online Published: September 26, 2013

doi:10.5539/ijef.v5n10p118

URL: http://dx.doi.org/10.5539/ijef.v5n10p118

\begin{abstract}
This paper, selecting 775 listed companies from Shanghai and Shenzhen stock markets during three years from 2010 to 2012 as samples, studies the relationship between agency cost and capital structure, using two econometrics methods which are ordinary least squares (OLS) and panel data respectively. Capital structure is calculated by debt-to-asset ratio and long-term liability rate while agency cost is measured by overhead expenses rate and asset turnover rate. The result shows agency cost has a slightly negative correlation to debt-to-asset ratio and there is a positive and insignificant correlation relationship between long-term liability rate and agency cost.
\end{abstract}

Keywords: agency cost, capital structure, corporate governance

\section{Introduction}

Agency problem is one of the most important elements in modern corporate governance, which is normally related to free cash flow and information asymmetry. Such problem of capital structure originates from a classical paper named "Theory of the firm: managerial behavior, agency costs and ownership structure" (Jenson \& Meckling, 1976), which integrates elements from the theory of agency, the theory of property rights and the finance to develop a theory of the ownership structure of the firm.

Jenson and Meckling firstly defined the concept of agency costs, showed its relationship to the 'separation and control' issue, investigated the nature of the agency costs generated by the existence of debt and outside equity, demonstrated who bears costs and why, and investigated the Pareto optimality of their existence. They also provide a new definition of the firm, and show how their analysis of the factors influencing the creation and issuance of debt and equity claims is a special case of the supply side of the completeness of markets problem. Based on thus essential conclusion, this paper tries to select proper statistic indicator with econometric instrument to explain the relationship between agency cost and capital structure of Chinese listed companies. Hopefully, it could provide feasible suggestion to optimize listed companies' governance structure.

\section{Literature Review}

Western academic researchers have paid much attention to the analysis of how capital structure affecting agency costs of corporate in both theoretical and practical areas since 1970s, and it has made gained significant progress.

The most well-know outcomes are the following 3:

1) Incentive model

The incentive model believes that capital structure would influence the level of managers' endeavor and behavioral choice, thereby, it also had effect on corporate turnover, agency cost and market value;

2) Signaling model

The second model is the signaling model, which mentions capital structure would affect the judgment of investors to the situation of companies together with agency cost and market value.

3) Controlling model

The final one is controlling model, which figures out it would have impact on the allocation of corporate control, thus the agency cost and market value would also be changed.

The above 3 models indicate that capital structure is one of the most important sides among corporate 
governance and has quite a large effect on corporate agency cost and market value. Recently, many economists and financial analysts have verified that it would be helpful for reducing corporate agency cost by means of improving managers' shareholding ratio, debt/equity ratio and ownership concentration respectively.

Previous researches mostly analyzes the relationship between capital structure and corporate performance due to difficulties in measuring agency cost when they are doing empirical researches on this issue. It should also be noticed that ownership structure plays an important role in capital structure and related researches are more concentrated on relationship between ownership structure and corporate performance especially internal shareholding ratio and firm's performance. Such literatures do exist which directly analyzes ownership structure and agency cost, for example Sung et al. (1994), free cash flow and inferior ownership ratio are used to measure agency cost in this paper, it draws a conclusion that issuing risk protective bond has much more positive effect than issuing non-risk protective bond on shareholder wealth. At the same time, because shareholder wealth has negative correlation with agency cost, it can be deduced that agency cost could be reduced by event risk provision and shareholder wealth would be added naturally. Ang et al (2000) figures out agency cost could be replaced by administrative expenses rate ratio (administrative expense /turnover) and assets activity ratio (turnover/total asset). It suggests that agency cost will arise when there is only external managers but not internal managers; shareholding ratio has negative correlation with agency cost; numbers of non-managerial shareholder has positive correlation with agency cost; agency cost will go down under effective supervision of banks. Singh and Davidson (2003) select huge companies data as sample to do similar research. More over, Anderson et al. (2003) begins to discuss how original race ownership would affect debt agency cost and it figures out original race ownership are quite popular in huge public companies and it was helpful for allaying conflict between shareholders and creditors.

The common point of the above literatures is: optimal capital structure will improve the efficiency of corporate governance, alleviate contradictory between client and agent. It could also restrain moral hazard of agent, decrease agency cost and eventually increase firm value. However, they do all the researches are under complete competition market and rational investment hypothesis together with contract theory of capital structure. They believe all of the agency cost would be undertaken by agent (Arrow, 1986). Obviously, it is unreasonable, in fact, clients have to control moral hazard and related agency cost by themselves.

Such researches done by Chinese domestic researchers make use of administrative expense ratio and total asset turnover to estimate agency cost between shareholders and managers, which is used to analyze the effect on agency cost. Looking up Chinese domestic research outcome, we can summarize that the most frequently used indicators are administrative expense ratio and total asset turnover as the substitution of agency cost.

Song et al. (2005) found out agency cost had negative correlation with ownership concentration and had positive correlation with ownership balance. Zhang et al. (2005) believes that managers' shareholding ratio had obviously negative correlation with ownership agency cost; state owned ratio and circulation ratio were strongly positive correlated with ownership agency cost; debt ratio and legal person share ratio and the first major shareholders did not have negative correlation. Characters of final controller does not influence firm's agency cost positively but negatively according to Tang xue song and Zhou xiao su (2005). In Ge bang liang and Jiang mei fang (2010)'s paper, the authors figure out ownership concentration have nothing with agency cost but positively correlated with total asset turnover, fixed leverage ratio are negatively correlated with total asset turnover but capital structure are positively correlated with administrative expenses rate.

Based on the above Chinese domestic research conclusions we can find out, due to restrictive data and difficulties in determining agency cost, they are divided into 2 categories: firstly, they adopt traditional research methodology starting from current situation of Chinese listed companies capital structure on the basis of contract theory to deduce the effect on agency cost and propose relative countermeasures (Zhu ye, 2003). The other kind of researchers mainly make use of modern empirical methodology to indirectly judge how capital structure affects agency cost by means of testing firm's performance.

Many financial indicators have already been used to discuss such issue, such as ownership structure, board features. They partially explained the effect on agency cost and many empirical researches seldomly used panel data which could probably fully evaluate firm's agency cost. This paper tries to adopt 2 long term solvency indicators to reflect capital structure and 2 variables to estimate agency cost. Panel data is also used to analyze the relationship between them, hopefully, it could provide feasible suggestion to Chinese listed companies of optimizing corporate governance.

\section{Research Design}

In terms of capital structure contract theory together with specialty of Chinese listed company, this paper makes 
the following hypotheses:

H1: agency cost is the decreasing function of asset/debt ratio under the same circumstance.

Theoretically, debt raising could at least reduce agency cost in the following 4 aspects under an effective debt constraint: at first, because the principal and interest have to be paid in time, it will contribute to prevent managers from consuming free cash flow arbitrarily and overinvestment. Managers will be forced to keep promise to pay future cash flow that adheres to debt agreement, thus will lead to reduction of arbitrage cash flow and agency cost. Secondly, the increasing of debt raising would relatively increase managers' shareholding ratio especially when firms could acquire enough debt raising, managers' shareholding ratio would be added by reducing shareholders investment or by share repurchasing. Therefore, debt has the incentive effect on managers (Agrawal \& Mandelker, 1987). Thirdly,debt raising would affect corporate operating risk and structure (Cang ze, 1989). Managers will undertake more risk than shareholders and creditors due to specificity of human capital when firms are facing with bankruptcy because of debt, so debt raising will push managers forward to trying their best to manage and eliminating risk of bankruptcy. (Grossman \& Hart, 1982). The added debt enhance possibility of bankruptcy and unemployment of managers (Safieddine et al., 1999); eventually, debt raising will quite influence on reliability of corporate ownership status together with agent competition. Recently, with the development of Chinese state owned companies' financial revolution, the consummate bankruptcy system and delisting system, bank-enterprise relationship according with market economy requirement has been established, constraints on debt raising has also been strengthened. Empirical research of testing on trade off theory done by Misrules (1983) shows, changes of ordinary stock is positively correlated with changes of firms'financial leverage but firms' value is negatively correlated with debt level. Modern corporate structure believes, with operating leverage to help, if managers could find out optimal corporate structure, WACC will be reduced and firm value will be added as well. However, if debt adding, firm's financial status security is getting worse which will lead to increasing of cost of capital. Alternatively, raising condition will getting deteriorate and agency cost will also be added. In conclusion, this paper believes improving debt raising rationally will help to reduce agency cost.

H2: Agency cost is the increasing function of long term debt ratio under the same circumstance.

This is because long term debt cost is relatively higher with fixed repayment terms, and managers are easy to get access into long term capital operating process. Meanwhile, short term debt cost is relatively lower with shorter repayment term, and managers are difficult to manipulate it. Therefore, if we increase long term debt quantity, agency cost of firm will be increased as well.

\section{Research Design}

\subsection{Variable Explanation}

In order to test the above hypothesis, this paper tries to define some variables such as: agency cost,debt/asset ratio and long term debt ratio.

\subsubsection{Agency Cost}

Concerning about how to measure agency cost, Prowse has ever referred cash and tradable security/total asset to measuring agency cost. He believes that the more current assets within company,the more possibility to select inferior portfolio. After that, Sung (Sung, 1994) measures agency cost by free cash flow and internal ownership ratio in his paper. Ang, Cole and Lin (2000) combines agency cost with ownership structure directly by empirical research, administrative expenses rate (including management expense,operating expense and financial cost) and total asset turnover were used to evaluate agency cost starting from the premise of zero agency cost. Sing and Davidson developed Ang, Cole and Lin's conclusion, which estimates agency cost by the sum of total asset turnover, selling expense and management expense with sales revenue. Meanwhile, it implys the relationship between ownership, corporate governance and agency cost by univariate and multivariate analysis.

Looking back at Chinese domestic empirical research about such issue, we can find out that administrative expenses rate and total asset turnover are the most frequently adopted as the substitution of agency cost. (Gao Lei, Li Fengfang \& Zhang Jie, 2010).

It considering transportation fee, installment fee and packet fee are also included in administrative expenses rate, which is not directly related to agency cost,this paper tries to make a slight change in measuring agency cost by using administrative expenses rate and total asset turnover. Inevitably, these two index will have technical error, but it can be controlled within believable range with the help of selecting different area of industries and inter temporal sample. 
(1) Administrative expenses rate (administrative expense/sales revenue)

Agency cost could be divided into real consume and idle consume according to Lv changjiang (2002). Real consume is normally referring to purchasing luxurious commodity, cash outflow of office decoration. As those expenses are regarded as administrative expenses which are also closely related with real consume behaviour, they could be chosen to measure agency cost. It is also supposed that the more administrative expenses rate (AER), the more agency cost, and vice versa. Administrative expenses rate could be recorded as $Y_{l t}$.

(2)Total asset turnover (sales revenue/average total asset)

The other form of agency cost is idle consume which means hard work is replaced by idle enjoyment by managers which will lead to client wealth dead weight loss in that client welfare maximum is deviated from agent decision. This loss does not lead to cash outflow but decreasing of sales revenue ability of the same size asset companies, as a result, we could apply total asset turnover to evaluate agency cost. Unfortunately, without the hypothesis of zero agency cost, we adapt Singh and Davidson's methodology (2003) using total asset turnover to measure agency cost, then the more total asset turnover, the less the agency cost and vice versa. Total asset turnover (TAT) is simplified as $Y_{2 t}$.

\subsubsection{Capital Structure Variable}

This paper selects firms' long term liability index to be explanatory variable due to going concern hypothesis which includes debt/asset ratio (D/A) and long tern debt ratio (LTD).

$$
\begin{aligned}
\text { debt / asset } & =X_{1 t}=\frac{\text { totaldebt }}{\text { totalasset }} \\
\text { longtermde btratio } & =X_{2 t}=\frac{\text { longtermde bt }}{\text { totalasset }}
\end{aligned}
$$

\subsection{Research Methodology}

This paper selects panel data of 2010-2012, firstly uses univariate analysis to verify relationship be capital structure and agency cost of Chinese listed companies, after that OLS will be used to do regression analysis.

The analysis of panel or longitudinal data is the subject of one of the most active and innovative bodies of literature in econometrics, partly because panel data provide such a rich environment for the development of estimation techniques and theoretical results. In more practical terms, however, researchers have been able to use time-series cross-sectional data to examine issues that could not be studied in either cross-sectional or time-series settings alone.

The basic framework for this discussion is a regression model of the form

$$
Y_{i t}=\alpha_{i t}+\beta_{i} X_{i t}+\xi_{i t}
$$

Where $X_{i t}=\left(x_{1 t}, \ldots x_{k t}\right)$ are the explanatory variables, $Y_{i t}=\left(y_{1 t}, \ldots y_{k t}\right)$ are explained variables, $\alpha_{i t}$ is constant, $\beta_{i}^{\prime}=\left(\beta_{1 i}, \ldots \beta_{k i}\right)$ are the regressors or covariants, $\xi_{i t}=\left(\xi_{1 t}, \ldots \xi_{k t}\right)$ is disturbance, i stands for the $i^{\text {th }}$ sample, $\mathrm{t}$ stands for the $t^{\text {th }}$ year.

Table 1. Variables equation

\begin{tabular}{cccc}
\hline Variables & Items & Specific indicator & Abbreviation \\
\hline \multirow{2}{*}{ Explained Variables } & Agency cost & Administrative expenses rate $Y_{l t}$. & AER \\
& & Total asset turnover $Y_{2 t}$ & TAT \\
\multirow{3}{*}{ Explanatory Variables } & Capital & debt/asset ratio $X_{l t}$. & D/A \\
& structure & long term debt ratio $X_{2 t}$. & LTD \\
\hline
\end{tabular}

It also has the implicit hypothesis: the disturbance is assumed to have conditional expected value zero at every observation, which we write as:

$$
E\left[\varepsilon_{i} / X\right]=0
$$

Panel data is used in establishing model 1 , although fixed effect model or random effect model should also be used, in comparing these 2 models Hausman test is a much better instrument to test it. 
Although 775 listed companies are selected as research sample, the amount of observation data in the 3 years are 2325 , due to some reason we have to delete some missing samples which probably affect regression results.

\subsection{Sample Selection}

Relevant information about ownership and financial structure of Chinese listed companies are usually disclosed in their annual report. It is not difficult to find out such listed companies from Shanghai \& Shenzheng A Stock Markets, therefore, we choose 1088 listed companies between 2010-2012 and screen them according to the following criteria: (1)due to special capital structure, financial insurance companies and hi-tech companies are eliminated; (2)because special treated companies are not in normal raising situation, they are also deleted; (3) companies without fully disclosed their financial information are not included; (4)since extreme value is not reliable for our research, we get rid of sample with abnormal independent variables. Finally, 775 listed companies are selected as research sample, the amount of observation data in the 3 years are all 2325. Sample is distributed averagely within 19 kinds of industries as is shown in table 2, most of the industry sample number is more than 10 but less than 50 which is quite helpful for our result. All of the data comes from CSMAR (Chinese listed companies' financial database provided by Shenzhen guo tai an information and technology company).

Table 2. Industry distribution

\begin{tabular}{|c|c|c|c|c|c|}
\hline Industry & Frequency & Percentage $(\%)$ & Industry & Frequency & Percentage $(\%)$ \\
\hline $\begin{array}{l}\text { Agriculture } \backslash \text { forestry } \backslash f i \\
\text { shing } \backslash \text { farming }\end{array}$ & 15 & 1.94 & Biology & 41 & 5.29 \\
\hline Mining & 17 & 1.81 & $\begin{array}{c}\text { Other } \\
\text { manufacturing }\end{array}$ & 15 & 1.94 \\
\hline $\begin{array}{c}\text { Food, beverage, } \\
\text { tabaco }\end{array}$ & 39 & 5.03 & Electricity & 31 & 4 \\
\hline Fabric & 36 & 4.65 & Construction & 23 & 2.97 \\
\hline Painting & 14 & 1.81 & Warehouse & 39 & 5.03 \\
\hline Petrol & 82 & 10.58 & $\begin{array}{c}\text { Whole sale and } \\
\text { retail }\end{array}$ & 51 & 6.58 \\
\hline Transportation & 49 & 6.32 & Real estate & 35 & 4.52 \\
\hline Metal & 79 & 10.19 & Social service & 30 & 3.87 \\
\hline Machinery & 149 & 19.23 & Compound & 30 & 3.87 \\
\hline Total & & & & 775 & 100 \\
\hline
\end{tabular}

During the process of doing such research, many other indexes should be considered, however, due to data access problem only 2 indexes are selected which might not be full to explain the issue. Apart from it, adopting replacing index to measure agency cost of firm is an indirect methodology which could not fully stand for companies' agency cost. Meanwhile, the impact of those indexes on agency cost is quite complex, administrative expense rate and total asset turnover can only reflect part of agency cost but not the whole.

During the process of doing analysis on capital structure, only long term liability index is adopted, which are debt-to-asset ratio and long term debt ratio without subdividing capital structure. But according to current status of Chinese listed company, capital structure is not rational, they prefer equity raising to debt raising. Among debt raising structure, current liability is more than non current liability debt which brought unfavorable factors to corporate governance and will lead to agency cost increasing eventually. Therefore, in doing empirical research, it is desirable to differentiate the relationship between long term liability ratio, short term liability ratio and corporate capital structure.

In the established model, there is an implicit hypothesis of $E\left[\varepsilon_{i} / X\right]=0$, which means any other factors will not have impact on capital structure. However, apart from 2 main index chosen by this paper, actually many other factors have quite a large effect on firm's capital structure. For instance, company size, growth and industry character, they all affect firm's performance. Different industry will have different impact on firm value even lead to changes in agency cost. It is really a pity that the 775 listed companies spreading into 19 kinds of industry 
which will finally influence on regression result.

\section{Statistic Result and Empirical Analysis}

\subsection{Descriptive Statistic and Correlation Analysis}

Table 3 and 4 show us simple statistical analysis of variables and their correlation. Simply statistic result could be seen in table 3 which shows that the stability of total asset turnover is better than administrative expense rate. And maybe AER is more easier to be manipulated in that ROE is normally used to estimate listed companies when they come across with IPO, rights issue, ST and PT. It is also used to process earnings management by listed companies.

The other outcome shows long term debt ratio is much stable than asset debt ratio with much bigger fluctuation. The result probably comes from changing in debt management or firms' value decreasing, alternatively, different industries and area will lead to large distance between samples' sales revenue and asset size.

Table 3. Descriptive statistic analysis

\begin{tabular}{lcccc}
\hline & $Y_{1 t}$ & $Y_{2 t}$ & $X_{1 t}$ & $X_{2 t}$ \\
\hline Mean & 0.076 & 0.799 & 0.500 & 0.165 \\
Media & 0.062 & 0.661 & 0.507 & 0.094 \\
Maximum & 1.013 & 7.910 & 4.781 & 0.924 \\
Minimum & 0.002 & 0 & 0.009 & 0 \\
Standard deviation & 0.0612 & 0.608 & 0.203 & 0.185 \\
Skewness & 4.722 & 3.175 & 4.081 & 1.358 \\
Kurtosis & 52.400 & 23.128 & 88.672 & 4.302 \\
\hline
\end{tabular}

Table 4. correlation analysis

\begin{tabular}{ccccc}
\hline & $Y_{1 t}$ & $Y_{2 t}$ & $X_{1 t}$ & $X_{2 t}$ \\
\hline$Y_{1 t}$ & 1.000 & & & \\
$Y_{2 t}$ & -0.299 & 1.000 & & \\
$X_{1 t}$ & -0.122 & 0.039 & 1.000 & \\
$X_{2 t}$ & -0.023 & -0.194 & 0.163 & 1.000 \\
\hline
\end{tabular}

Table 4 reflects the correlation relationship between such variables. According to the above results, explanatory variables have weak correlation which is quite reasonable when selecting index. Nevertheless, we can see that improving debt ratio will have incentive effect on managers, that is to say, agency cost will be reduced which is matched with H1. However, because long term debt ratio has negative correlation with total asset turnover which matches $\mathrm{H} 2$, but does not strongly negatively correlated with AER which is opposite to H2.

\subsection{Regression Analysis}

According to multiple-regression model (1), in order to test the influence of capital structure on agency cost, asset debt ratio and long term debt ratio to administrative expense rate and total asset turnover are regressed respectively, with the help of statistic software Eviews 7.0, we have the following results: 
Table 5. Regression result

\begin{tabular}{lllll}
\hline Item & $Y_{l t}$ & & $Y_{2 t}$ & \\
\hline Variables & Model 1 & Model 2 & Model 1 & Model 2 \\
$\alpha_{i t}$ & $0.095(27.621)^{* * *}$ & $0.095(28.258)^{* * *}$ & $0.802(23.914)^{* * *}$ & $0.904(54.375)^{* * *}$ \\
$X_{l t}$ & $-0.037(-5.794)^{* * *}$ & $-0.037(-5.985)^{* * *}$ & $0.217(3.509)^{* *}$ & \\
$X_{2 t}$ & $0.001(0.0140)$ & & $-0.676(-9.984)^{* * *}$ & $-0.637(-9.516)^{* * *}$ \\
R-squared/A-R-squared & $0.015 / 0.014$ & $0.015 / 0.015$ & $0.043 / 0.042$ & $0.038 / 0.037$ \\
F-value & 17.396 & 35.819 & 51.654 & 90.554 \\
\hline
\end{tabular}

Note: in bracket figure,t stands for test value, ${ }^{*}$ stands for significant under level $0.1,{ }^{* *}$ stands for significant under level $0.05,{ }^{* * *}$ stands for significant under level 0.01 .

In model 1, asset debt ratio is quite significant in statistic; model parametric joint significance testing ( $\mathrm{F}$ testing) is significant as well, in other word, asset debt ratio has systematic effect on administrative expense rate. However, long term debt ratio does not pass the test. If we delete the unpassed index of $X_{2 t}$ and do regression again, we can find out $\mathrm{F}$ testing is much higher than model 1 but the total goodness of fit is still low. The reason why we get low goodness of fit lies to only considering capital structure as explanatory variable and ignoring non capital structure factors' effect on AER, therefore, the adjusted $R^{2}$ value are low in both 2 models. But it only saying models, we care much more about how explanatory variables affect explained variables. Summarized upon the regression result, it indicates that the impact is negative which verified $\mathrm{H} 1$ once again.

Comparing the whole test of goodness of fit in model 1 of $Y_{2 t}$ with $\mathrm{F}$ value, we deduce a more significant result and asset debt ratio has weak correlation with total asset turnover, at the same time, long term debt ratio is significant in statistic but is negatively correlated with total asset turnover. Deleting weak significant index of asset debt ratio, we can find out that model 2 has higher $\mathrm{F}$ value but lower $\mathrm{t}$ test in long term debt ratio than model 1. Besides it, the total goodness of fit is worse than model 1. In a word, the regression result of $Y_{2 t}$ matches with $\mathrm{H} 2$, that is to say, long term debt ratio has negative impact on agency cost, which also means the higher long term debt ratio in company the less financial constraint of other debt and the weaker impact on agency cost.

\section{Conclusion and Suggestion}

This paper selects 775 listed companies from Shanghai and Shenzhen stock markets during three years from 2010 to 2012 as samples, studies the relationship between agency cost and capital structure,using two econometrics methods including the ordinary least squares and panel data.Capital structure is calculated by debt-to-asset ratio and long-term liability rate while agency cost is measured by overhead expenses rate and asset turnover rate. 2 hypotheses is made to establish regression model 1 and model 2, then we do empirical analysis.

Results indicate that, agency cost has a slight negative correlation to debt-to-asset ratio and there is a positive and insignificant correlation relationship between long-term liability rate and agency cost. Those conclusions match the hypothesis made and could reflect some practical problems in corporate governance of Chinese listed companies to some extent.

Going back to the first part of this paper to look at literature review again, we can summarize that most of empirical researches are function of ownership structure on agency cost. State-owned share ratio,legal person shareholding ratio, the first shareholder ratio and manager shareholding ratio are the most frequently adopted index to test their impact on agency cost. It basically complies with current status of Chinese listed companies' ownership structure specialty, state-owned share ratio and legal person shareholding ratio dominate the main part and most of the first shareholders are state owned with less minority shareholders weakening the constraint balance. Many theoretical and practical results have proved, the most influencing factor is ownership structure which is the concentrated reflection of firm owners' responsibility and obligation. It will determine and affect firm's behavior and value, debt structure has to be discussed after considering it.

\section{Main Contribution}

This paper tries to analyze the relationship between Chinese listed companies agency cost and capital structure by quantitative methodology and find out specific conclusion, which is politically meaningful to consummate Chinese listed companies' capital structure. Because capital structure has directly impact on shareholders, managers and creditors contractual relationship and in order to consummate Chinese listed companies' capital 
structure and eventually reduce agency cost. One of the most effective ways to do it is to consummate debt restraint system which includes credit measurement system, debt contract and bankruptcy system, what is more, good will system also needs to be considered. For Chinese listed companies, in a word, to improve debt-to-asset ratio rationally will be useful to reduce long term liability ratio even to the reduction of agency cost.

\section{References}

Agrawal, A., \& Gershon, N. M. (1987). Managerial incentives and corporate investment and financing decisions. Journal of Finance, 42(4), 823-837. http://dx.doi.org/10.1111/j.1540-6261.1987.tb03914.x

Anderson, R. C., Mansi, S. A., \& Reeb, D. M. (2003). Founding family ownership and the agency cost of debt. Journal of Financial Economics, 68(2), 263-285. http://dx.doi.org/10.1016/S0304-405X(03)00067-9

Ang, J. S., Cole, R. A., \& Lin, J. W. (2000). Agency costs and ownership structure. Journal of Finance, 55(1), 81-106. http://dx.doi.org/10.1111/0022-1082.00201

Fleming, G., Heaney, R., \& McCosker, R. (2005). Agency costs and ownership structure in Australia. Pacific-Basin Finance Journal, 13(1), 29-52. http://dx.doi.org/10.1016/j.pacfin.2004.04.001

Ge, B. L., \& Jiang, M. F. (2008). Empirical research of relationship between capital structure and agency cost of Chinese listed company. Special Zone Economy, (2), 104-105.

Hao, C., Gong, Y., \& Sun, L. (2010). An empirical study of the impact of governance elements on agency cost-data from hu \& shen stock markets of 2000-2010 in China. Soft Science, (10), 123-128.

Jensen, M. C., \& Meckling, W. H. (1976). Theory of firm: Managerial behavior, agency costs and capital $\begin{array}{lllll}\text { structure. Journal of } & \text { Financial }\end{array}$ http://dx.doi.org/10.1016/0304-405X(76)90026-X

Li, S. O. (2010). Agency cost and agency efficiency. Economic Research Journal, (1), 102-113.

Lv, C., \& Zhang, Y. (2002). The measurement of agency cost and its relation with cash dividend. Finance, (4), 3-7.

Singh, M., \& Davidson, W. N. (2003). Agency costs, owership structure and corporate governance medianisms. Journal of Banking and Finance, 27(5), 793-806. http://dx.doi.org/10.1016/S0378-4266(01)00260-6

Song, L., \& Han, L. L. (2005). State holding, turnover of uppermost decision-maker and firm performance. Nankai Business Review, (1), 32-36.

Sung, C., Klein, D., \& Padmaraj, R. (1994). Event risk bond covenants, agency cost of debt and equity, and stockholder wealth. Financial Management, 23(4).

Tang, X., \& Zhou, X. (2005). Empirical research of final controller's characteristic and agency cost. The $4^{\text {th }}$ accounting empirical international forum of China.

Zhang, H., \& Liu, S. (2009). Empirical study of listed company's agency cost. Communication of Finance and Accounting, (3), 29-34.

Zhang, Z., Song, L., \& Zhang, Q. (2005). The analysis of the impacts of the listed companies capital structure on the equity agency cost. Accounting Research, (8), 44-50.

Zhu, Y. (2003). Research on Chinese listed company capital structure. Shanghai: Fudan University Press.

\section{Copyrights}

Copyright for this article is retained by the author(s), with first publication rights granted to the journal.

This is an open-access article distributed under the terms and conditions of the Creative Commons Attribution license (http://creativecommons.org/licenses/by/3.0/). 